\title{
TECHNOLOGICAL CHARACTERIZATION OF TALC ORE FROM CAÇAPAVA DO SUL, RS-BRAZIL FOR DEVELOPMENT OF A PROCESS ROUTE
}

\author{
T. R. C. OLIVEIRA ${ }^{1}$, M. P. PAIVA ${ }^{2}$ \\ Federal University of Rio Grande do Sul (UFRGS), Federal University of Pampa (UNIPAMPA) \\ taistngminer@ufrgs.br ${ }^{1}$
}

Submitted 15/11/2017 - Acepted: 30/11/2017

DOI: $10.15628 /$ holos. 2017.6600

\section{ABSTRACT}

This paper provides technological characterization and preliminary studies for the concentration of talc ore from the municipality of Caçapava do Sul, RS - Brazil, for the purpose of defining its process route. The characterization was made by in bench channel sampling, preparation of the material by comminution, followed by homogenization, fractionation, and analyses of particle size, mineralogy, chemical composition, brightness, density and humidity of the sampled material. Afterwards, magnetic separation studies were carried out using Davis tube and leaching, in order to reduce the impurities, which consisted mainly of iron oxide contamination. After preparation of the sample, it
\end{abstract}

was possible to obtain a fine material of approximately $65 \%$ passing $37 \mu \mathrm{m}$, with similar brightness values between all samples despite a variable distribution of $\mathrm{Fe}$, $\mathrm{Ca}, \mathrm{Mg}$ and $\mathrm{Al}$ contents. The best results of the study occurred for the sample with a granulometric cut of $100 \#$ subjected to a magnetic separation of $4050 \mathrm{G}$ and later leaching at $80{ }^{\circ} \mathrm{C}$ for a time of $60 \mathrm{~min}$. A maximum brightness of $72.3 \%$ was achieved, with an increase in brightness of $10.3 \%$ in relation to the initial brightness. This product could be applied to the paint, insecticide, textile and paper industries, requiring complementary characterization to fit further specifications.

KEYWORDS: talc; technological characterization; iron impurities; processing. 


\section{INTRODUCTION}

Talc, a noble mineral for cosmetics, paints, and paper, may also be used for ceramics, rubber, insecticides and fertilizers. It occurs in very fine granulometry, in rocks of powdery texture and often has associations with impurities such as titanium, serpentine, dolomite, magnesite, limestone, manganese and iron oxides, sometimes in the form of gangue minerals, sometimes within its crystalline lattice. These impurities influence the variability of ore properties including whiteness, granulometry, texture, chemical composition and hydrophobicity (Pontes \& Almeida, 2005).

According to data released in the Mineral Summary of 2015, by the National Department of Mineral Production (DNPM), the production of talc beneficiated in the year 2014 had an increase of $36.9 \%$. Compared to the previous year, this increase was $28.3 \%$, while imports grew $8.6 \%$.

Technological characterization is defined as a fundamental step to optimize the utilization of a mineral resource and allows for precise identification of inefficiencies and losses in processes, enabling an increase of the global yield and correct dimensioning of the beneficiation route (Neumann et al., 2004).

In this context, this work provides technological characterization and preliminary studies for the concentration of a talc ore, of a deposit located in Caçapava do Sul-RS, for the purpose of defining its process route.

\section{BIBLIOGRAFHIC REVIEW}

\subsection{Talc}

Pontes \& Almeida (2005) describe talc as hydrated magnesium filosilicate of the chemical formula $\mathrm{Mg}_{3}\left(\mathrm{Si}_{4} \mathrm{O}_{10}\right)(\mathrm{OH})_{2}$, with "tot" spatial arrangement represented by two tetrahedral sheets t- linked by Van Der Waals bonds and formed by atoms of silicon and oxygen (siloxane sheet) that surround an octahedral sheet -o formed by magnesium and hydroxyl (brucite leaf).

According to Camara (2003), talc can occur in two different symmetries, monoclinic (more common) and triclinic, wherein the crystalline structure (Figure 1) presents a triple layer, being a sheet of magnesium hydroxide and two leaves composed of tetrahedra of $\mathrm{SiO}_{4}{ }^{-4}$. The external siliceous faces are apolar and oleophilic, hydrophobic, aerophilic and inert.

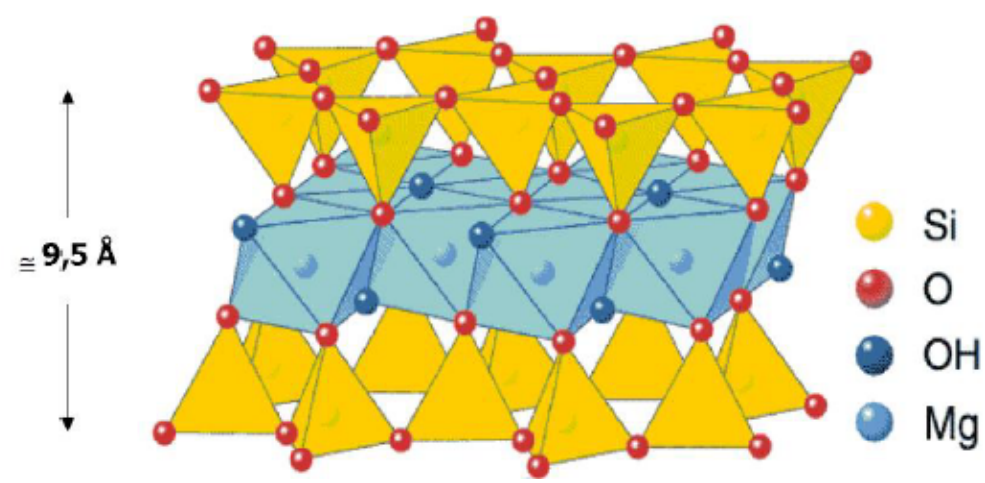

Figure 1: Crystal structure of talc ore (Camara, 2003). 
Monte et al. (2003) considers that the physicochemical properties of talc products should vary according to the destination of the product as explained in Table 1, emphasizing the importance of characteristics such as granulometry, degree of purity and color of the product. The Table 1 shows some parameters required by different industries depending on the application of the talc ore.

Table 1: Industrial specifications.

\begin{tabular}{|c|c|c|c|c|c|c|}
\hline Use & Size & Chemical composition & Brightness & Mineralogy & Properties & Others \\
\hline Paint (Spreading) & $\begin{array}{l}100 \%<200 \# \\
96,5 \%<325 \#\end{array}$ & $\begin{array}{l}\mathrm{SiO}_{2}+\mathrm{MgO} \geq 75 \% \mathrm{Al}_{2} \mathrm{O}_{3} \\
\leq 2 \% \mathrm{H} 2 \mathrm{O}+\mathrm{M} . \text { Vol. } \leq 1 \% \\
\text { Loss on ignition } \leq 7 \%\end{array}$ & 65 to 90 & $\begin{array}{l}\text { Lamellar } \\
\text { particles. }\end{array}$ & $\begin{array}{l}\text { Chemical inertia, } \\
\text { Hydrophobicity, } \\
\text { Brightness. }\end{array}$ & $\begin{array}{l}\text { Density } \\
2,8 \text { a } 2,9 .\end{array}$ \\
\hline Paint (Pigment) & $100 \%<325 \#$ & $\begin{array}{c}\mathrm{MgO}: 24 \text { to } 32 \% \\
\mathrm{SiO}_{2}: 50 \text { to } 65 \% \\
\mathrm{CaO} \leq 9 \% \\
\mathrm{MgO}+\mathrm{SiO} \geq 88 \% \\
\mathrm{CO} \leq 1 \% \\
\mathrm{Al}_{2} \mathrm{O}_{3}+\mathrm{Fe}_{2} \mathrm{O}_{3} \leq 6 \% \\
\mathrm{H}_{2} \mathrm{O}+\mathrm{MV} \leq 1 \% \text { Loss on } \\
\text { ignition } \leq 7 \%\end{array}$ & 80 to $90 \mathrm{GE}$ & $\begin{array}{l}\text { Fibrous particles } \\
\text { (tremolite). }\end{array}$ & $\begin{array}{c}\text { Brightness, } \\
\text { Chemical inertia, } \\
\text { Adsorption of oil } \\
27 \text { a } 31 \% .\end{array}$ & $\begin{array}{l}\text { Density } \\
2,8 \text { a } 2,9 .\end{array}$ \\
\hline Inseticide & $90 \%<325 \#$ & $\mathrm{pH} 8$ & ------ & --------- & Chemical inertia. & Adsorption. \\
\hline Textile & No sandy waste & ---------------- & ------- & No hard minerals. & Brightness & --------- \\
\hline $\begin{array}{c}\text { Paper } \\
\text { (Paper load) }\end{array}$ & $95 \%<400 \#$ & ------------------' & $\begin{array}{c}58 \text { to } \\
\mathrm{GE}\end{array}$ & --------------- & $\begin{array}{l}\text { Chemical inertia, } \\
\text { Hydrophobicity. }\end{array}$ & ------ \\
\hline $\begin{array}{l}\text { Plastic (Load and } \\
\text { support) }\end{array}$ & $100 \%<200 \#$ & & $\geq 77 \mathrm{GE}$ & Talc or pyrophyllite. & $\begin{array}{c}\text { Chemical inertia, } \\
\text { Brightness. }\end{array}$ & No humidity. \\
\hline Non-stick & $100 \%<325 \#$ & ----------------------- & $\geq 77 \mathrm{GE}$ & $\begin{array}{c}\text { Talc or } \\
\text { pyrophyllite. }\end{array}$ & $\begin{array}{c}\text { Chemical inertia, } \\
\text { Brightness. }\end{array}$ & Low acidity. \\
\hline
\end{tabular}

\section{GE = General Eletric Parameter}

With respect to the use of talc ore in the manufacture of paints, it is used as charge and pigment in external uses of surfaces exposed to abrasion and low visibility paints. On the other hand, in the production of valve rubbers, talc is used as a spray to lubricate molds and prevent the surfaces from binding during the manufacture of the product. In the textile industry, after reaching very fine granulometry, talc gives weight and blemishes cotton fabrics, twines and yarns (Fabris, 2006), being this same bleaching function exercised in the paper industry, besides acting as a load when incorporated into the mass and to avoid reactions with other materials used in papermaking (Campos, 2011).

\subsection{Geological Characterization}

The talc ore from this deposit originates from hydrothermal alteration processes of magnesium minerals, mainly olivine and orthopyroxenes, but may also occur from a process of regional metamorphism or contact with magnesian calcareous or ultrabasic rocks. This occurrence is associated with minerals of biotite, chlorite, serpentine and carbonates (Machado, 2016).

As for the local geology, it was observed that the talc mineral is deposited either intercalated or sometimes on the amphibolite, evidenced by the outcrop on the west side of the bench. The amphibolite in this deposit is a metamorphic rock of basic igneous origin (Winge, 2016), relatively hard with a presence of quartz that accompanies the shale of the deposit. 
To the west of the sampled basin, there are talc-filled fractures (Figure 2(a) and 2(b)) and quartz veins of $\sim 0.5 \mathrm{~cm}$ (Figure 2(c)). To the east of the sampled basin, talc ore predominates with varying degrees of weathering from medium to high. Mineral occurrences in medium weathering zones include: dolomite minerals $\left(\mathrm{CaMg}\left(\mathrm{CO}_{3}\right)_{2}\right)$, orthopyroxenes of the chemical formula $(\mathrm{Mg}$, $\mathrm{Fe})_{2} \mathrm{Si}_{2} \mathrm{O}_{6}$ (Figure 2(e)) and iron oxides (Fe2O3) with a content lower than that found in zones of high weathering. In high weathering zones, the presence of high levels of iron oxide occurs (Figure 2(d)), giving reddish coloration to the deposit, as observed by Walker (1967) when affirming that the coating of a great majority of the grains of these rocks by iron oxide films gives rise to the reddish color present in regions of the deposit. It should be noted that all such identifications were possible through X-Ray Fluorescence spectrometry analysis in samples taken from the deposit.
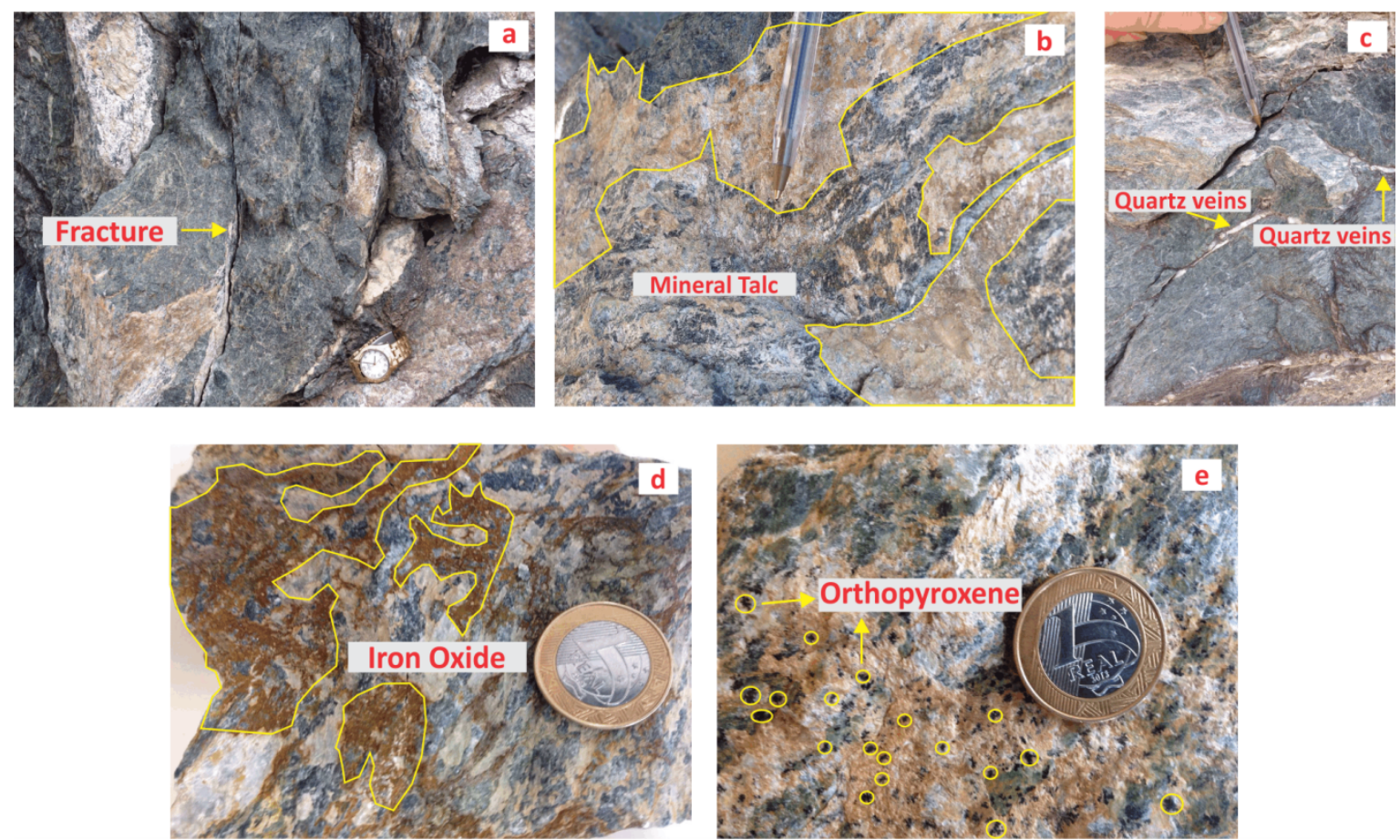

Figure 2: (a) Fracture; (b) mineral talc filling in the fractures; (c) quartz veins observed in the amphibolite; (d) iron oxide $\left(\mathrm{Fe}_{2} \mathrm{O}_{3}\right)$ e (e) orthopyroxene $\left((\mathrm{Mg}, \mathrm{Fe})_{2} \mathrm{Si}_{2} \mathrm{O}_{6}\right)$ identified by X-Ray Fluorescence Spectroscopy.

\subsection{Technological Characterization}

Fontes (2013) defines the technological characterization of a specularite iron ore as the gathering of information such as density, magnetic properties and others, allowing knowledge of the chemical and physical properties of a given ore. Such characterization aims at stipulating a beneficiation process route based on ore and market needs, seeking greater efficiency in the possible changes of small properties during the process.

The successful separation of minerals of interest by concentration operations depends on 3 basic conditions (Fundação Cristiano Ottoni, 2016):

i. liberation: where there is individualization of the species in order to make them free;

ii. differentiability: existence of a property (natural or induced) capable of differentiating the mineral species from each other (Table 2);

iii. dynamic separability: occurs when a compound force acts in the separation zone of the 
equipment by promoting different trajectories to the particles in response to the different characteristics of the material.

Table 2: Treatment Method through differentiability of minerals.

\begin{tabular}{c|c} 
Properties & Methods \\
\hline \hline Density & Liquid or dense medium \\
\hline Texture and friability & Comminution, classification or screening \\
\hline Magnetic Susceptibility & Magnetic Separation \\
\hline Surface reactivity & Flotation
\end{tabular}

According to Neumann et al. (2010), the technological characterization of an ore varies according to the mineralogy and its inherent properties, as well as the scope and objectives of the characterization. Thus, the characterization has four main stages, independent of each other, defined as follows:

i. fractionation of the sample: facilitates the identification of minerals, quantification of phases, and establishes some physical properties;

ii. phase identification: for example, clear and easy-to-interpret signal of concentrated minerals in fractionation;

iii. quantification of minerals;

iv. liberation of the mineral of interest: related to the minerals of the gangue, it is verified in several ranges of particle size.

\subsection{Leaching study}

Dissolution of the mineral by water or aqueous solution of a leaching agent is termed leaching. The basic characteristic of leaching is the ability to treat ores with low grades, based on the specificity of the leaching agent used, while keeping the mineral of value in a solid state. When this process occurs for the purposes of removing impurities, it is called reverse leaching (Heck, 2016).

When processing talc ore to reduce iron concentration, Fabris (2006), who used $4 \mathrm{M}$ hydrochloric acid $(\mathrm{HCl})$, with an initial sample mass of $5 \mathrm{~g}$ for $30 \mathrm{~min}$ and at a temperature of $80^{\circ} \mathrm{C}$, obtained positive results for iron extraction, in the order of $78.7 \%$. In this same study, by exceeding the time $(30 \mathrm{~min}$ ) of exposure of the sample to the acid, the brightness of the product was maintained. In addition, it was observed that temperature and time are determining factors in the iron dissociation process, proving efficacy of the tests by subjecting samples up to $80{ }^{\circ} \mathrm{C}$ and $30 \mathrm{~min}$, respectively.

Also, in order to reduce iron content within samples, Rodrigues (2010) carried out chemical attacks on flotation concentrate residues from soapstone handicrafts using $\mathrm{HCl}$, starting with the flotation concentrate with a brightness of $70.8 \%$ and obtaining a final product with maximum brightness of $86.5 \%$ using the following reactions:

$$
\begin{aligned}
& \mathrm{FeO}+\mathrm{HCl} \rightarrow \mathrm{FeCl}_{2}+\mathrm{H}_{2} \mathrm{O} \\
& \mathrm{Fe}_{2} \mathrm{O}_{3}+\mathrm{Fe}+6 \mathrm{HCl} \rightarrow 3 \mathrm{FeCl}_{2}+3 \mathrm{H}_{2} \mathrm{O}
\end{aligned}
$$


In the same work, Rodrigues (2010) when performing acid leaching in a crude sample of the fine $(<74 \mu \mathrm{m})$ soapstone, with initial brightness of $51.8 \%$, obtained a brightness of $77.4 \%$ in the product. To obtain these results, a solution of $4 \mathrm{M} \mathrm{HCl}$, of temperature around $80^{\circ} \mathrm{C}$, was used for a time of $60 \mathrm{~min}$.

The best brightness occurred in the higher reaction time (60 min), with temperature above $75^{\circ} \mathrm{C}$ and $\mathrm{HCl}$ concentrations above $3.5 \mathrm{M}$.

\subsection{Magnetic separation study}

Magnetic separation is an important method of processing for concentration and purification of ores, which occurs due to different individual responses associated between mineralogical species and a magnetic field. This magnetic field is determined in function of the response of a property called magnetic susceptibility (Silva, 2012).

Rodrigues (2010) carried out magnetic separation studies with samples of soapstone, using $20 \%$ solids and granulometry larger and smaller than $74 \mu \mathrm{m}$, in which magnetic fields $(3000,4300$ and $4900 \mathrm{G}$ ) and currents ( 3,5 and $7 \mathrm{~A}$ ) were used.

The best results were obtained in the particle size fraction smaller than $74 \mu \mathrm{m}$, because with the fraction greater than $74 \mu \mathrm{m}$ there were inclusions of oxidized iron particles in the talc beads due to the attraction generated by the magnetic field. The application of $4900 \mathrm{G}$ promoted a $6 \%$ increase in brightness.

Fontes (2013) applied low and high density magnetic fields to a specularite iron ore of 0.21 to $0.30 \mathrm{~mm}$ granulometry, in order to attract the particles and concentrate them. This concentration generated ferromagnetic material as a concentrated product in the order of $67 \%$, according to the distribution of the mass fractions of the material after magnetic separation.

Fontes (2013) states that low magnetic fields are applied to materials with high magnetic susceptibility, while high magnetic fields must be applied to paramagnetic materials, and considers the control of the feed rate to be important, that is, the speed and the flow with which the particles pass through the magnetic field, preferring a low velocity of the flow to prevent magnetic particles from being entrained with the non-magnetic particles.

\section{METHODOLOGY}

\subsection{Channel sampling}

The talc ore sample was collect by channel sampling along $47 \mathrm{~m}$ of the face of the bench, as seen in Figure 3, maintaining a constant average height between the base and the top of the channel with the following dimensions: width of $10 \mathrm{~cm}$ and depth of $4 \mathrm{~cm}$, previously demarcated, totaling $440 \mathrm{~kg}$ of sampled material. This step was preceded by the cleaning of the face of the bench to remove the chemical alteration (surface oxidation) of the rock.

The channel was sampled using a geological hammer, tip, slit and mallet, and all material collected, meter by meter, was collected directly in a plastic tray, positioned just below the lower level of the sampled channel, and stored in clean, identified plastic bags. 


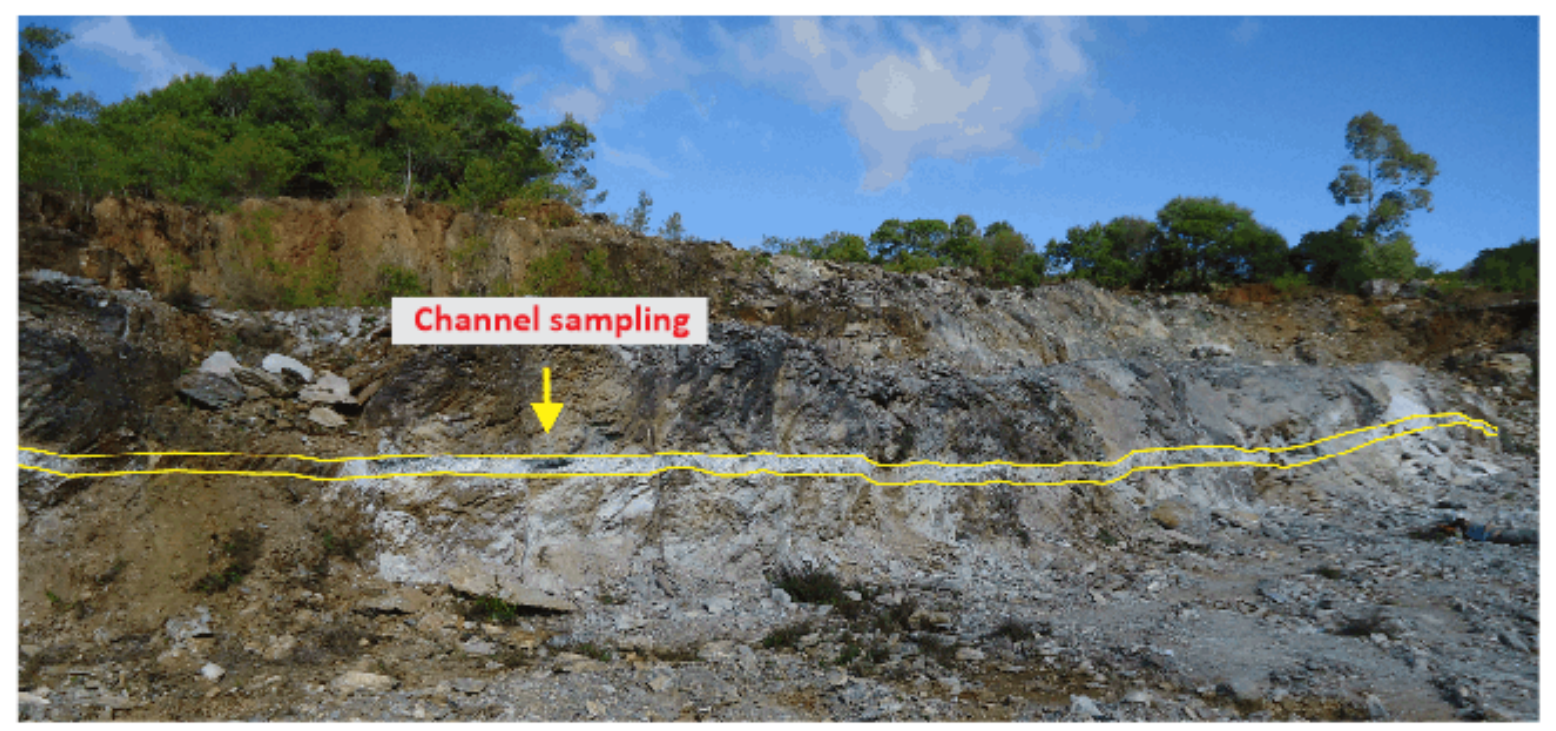

Figure 3: Channel sampling after collecting material.

\subsection{Sample preparation}

Sample preparation was performed by primary jaw crusher (Figure 4 (a)). Afterwards, the material was placed in a longitudinal pile mounted on a canvas for homogenization and fractionation (Góes et al., 2004), and stored in closed plastic containers to preserve the characteristics of the sample. An aliquot of $\sim 100 \mathrm{~kg}$ was subjected to secondary crushing by roller crushers, and the material was screened and sieved in a $3.35 \mathrm{~mm}$ mesh. The material retained in the mesh returned to the roller crusher to obtain a $100 \%<3.35 \mathrm{~mm}$ product (Figure 4 (b)).

Afterwards, all material was homogenized and fractionated by the longitudinal pile method and the aliquots obtained ( $6 \mathrm{~kg}$ ) were stored in plastic bags. Grinding tests were performed in ball mills and a ceramic jug with $\sim 3 \mathrm{~L}$ volume. Aliquots of $336.7 \mathrm{~g}$ of the crushed sample were milled at various times for a determination of the feed size F80 ( $80 \%$ passing) of $74 \mu \mathrm{m}$.
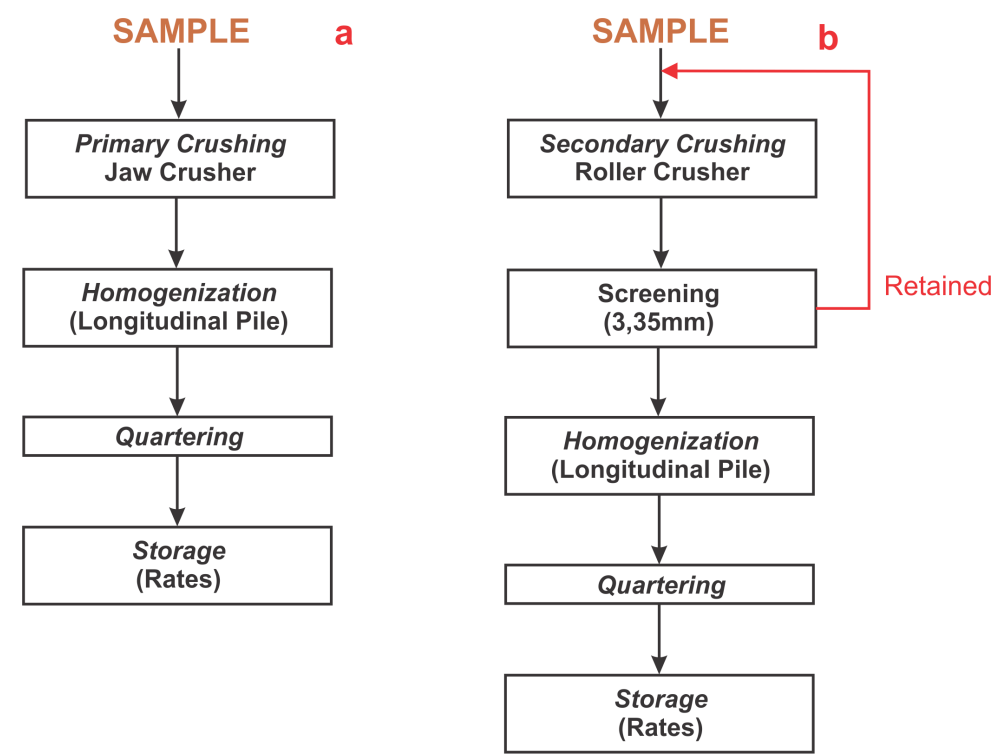

Figure 4: Sample preparation flowchart (a) primary crushing and (b) secondary crushing. 


\subsection{Particle size analysis}

The granulometric distribution was tested by wet sieving, with aliquots of 100 g of milled material in laboratory sieves of $20 \mathrm{~cm}$ diameter with the following meshes: 100 \# $(149 \mu \mathrm{m}), 150$ \# $(105 \mu \mathrm{m}), 200 \#(74 \mu \mathrm{m}), 325 \#(44 \mu \mathrm{m})$ and $400 \#(37 \mu \mathrm{m})$. The fractions retained in the sieves were vacuum filtered, oven dried at $50^{\circ} \mathrm{C}$ for $24 \mathrm{~h}$, and weighed.

\subsection{Density and humidity analyses}

The determination of the density of the talc ore was performed in duplicate by the method of picnometry (Sampaio et al., 2007). For such, a sample weight of approximately $1 \mathrm{~g}$ of heavy ground talc ore was used, along with an analytical balance, a pycnometer and distilled / deionized water.

Moisture analysis was performed in duplicate with aliquots of $5 \mathrm{~g}$ of ground talc ore sample, weighed on analytical balance, and oven dried at $105^{\circ} \mathrm{C}$ for $5 \mathrm{~h}$. Then the whole was taken to the desiccator for cooling and subsequent weighing. The procedure was repeated until reaching constant weight or difference of at least $0.001 \mathrm{~g}$.

\subsection{Mineralogical analysis}

The mineralogy of the talc ore was obtained by XRD analysis using a $20 \mathrm{~g}$ aliquot of material from the mill. This analysis was conducted by the Department of Physics/UFRGS using an X-ray diffractometer of the brand Siemens, model D-500, with curved graphite monochromator in the secondary beam and fixed anode tube of $\mathrm{Cu}$, operating at $40 \mathrm{kV}$ and $17.5 \mathrm{~mA}$.

\subsection{Chemical analysis}

The sample and the granulometric fractions were analyzed for the following elements: $\mathrm{Mg}$, $\mathrm{Ca}, \mathrm{Al}$ and $\mathrm{Fe}$, by the Atomic Flame Absorption Spectrometry method, at the Institute of Chemistry/UFRGS.

\subsection{Brightness analysis}

The whiteness analysis was performed according to ISO 2470 (ABNT, 2001), which assigns weight to reflectance in the range of 400 to $510 \mathrm{~nm}$ (Gonçalves, 2009). For this purpose, the aliquots were pulverized in an orbital disc mill, pressed for pellet formation and the reflectances obtained using a spectrophotometer previously calibrated with a white standard. The analyzes were carried out for the ground sample with and without a cut in the material passing 100 \#, with the granulometric fractions, and with the products of the magnetic separation and the leaching.

\subsection{Magnetic separation study}

Magnetic separation studies were performed with a Davis Tube separator (Inbras brand, EDT model), following the procedure described in the manufacturer's manual. The separation tests were fed with two types of samples previously milled: one sample with no granulometric 
cut and the other with a cut at $100 \#(150 \mu \mathrm{m})$. For these samples two magnetic fields of $3050 \mathrm{G}$ (1.4 A) and $4050 \mathrm{G}(2.0 \mathrm{~A})$ were applied.

\subsection{Leaching study}

The leaching studies were performed with aliquots of $5 \mathrm{~g}$ of talc ore. To these samples $4 \mathrm{M}$ $\mathrm{HCl}$ was added and the pulp (15\% w/w solids) from this mixture was stirred using a magnetic stirrer with rotation control and stirring ( $1000 \mathrm{rpm})$. Tests were performed at room temperature $\left(\sim 22^{\circ} \mathrm{C}\right)$ and heating $\left(\sim 80 \pm 5^{\circ} \mathrm{C}\right)$. The contact times were from 10 to $60 \mathrm{~min}$.

Leaching tests were performed with the non - magnetic product from the magnetic separation test of the sample (100 \#) and a field of $4050 \mathrm{G}(2.0 \mathrm{~A})$, and for the sample with a granulometric cut (100 \#). For these leaching tests, heating at $80 \pm 5^{\circ} \mathrm{C}$ for $60 \mathrm{~min}$ was used.

\section{RESULTS AND DISCUSSIONS}

\subsection{Characterization of the talc sample}

Table 3 summarizes the characterization results of the ground talc ore sample. The relative density of 2.7 coincides with the value of silicate minerals. In addition, it presented natural humidity $<1 \%$ and brightness of $\sim 60 \%$. The sample had high contents of the elements $(\mathrm{Mg}, \mathrm{Al}, \mathrm{Fe}$ and $\mathrm{Ca}$ ).

Table 3: Summary of the ground talc sample characterization.

\begin{tabular}{c|c|c|c|c|c|c|c} 
Relative Density & Humidity (\%) & Brightness (\%) & Fe (mg/g) & Ca (mg/g) & $\mathbf{M g}(\mathbf{m g} / \mathbf{g})$ & Al (mg/g) \\
\hline \hline 2,7 & 0,9 & 59 & 34 & 17 & 200 & 147
\end{tabular}

Five crystalline phases were identified in the mineralogical analysis: antigorite $(A)$, clinochlor (C) and magnesite (M), constituents of the ore minerals, along with dolomite (D) and talc (E). The peak of the talc phase presents high intensity, which shows the excellent crystallization of this phase, however, causing the non-observation of phases near the baseline, such as ferromagnetic phases (Figure 5). Also, some phases overlap characterizing low symmetry, common in polycrystalline samples. 


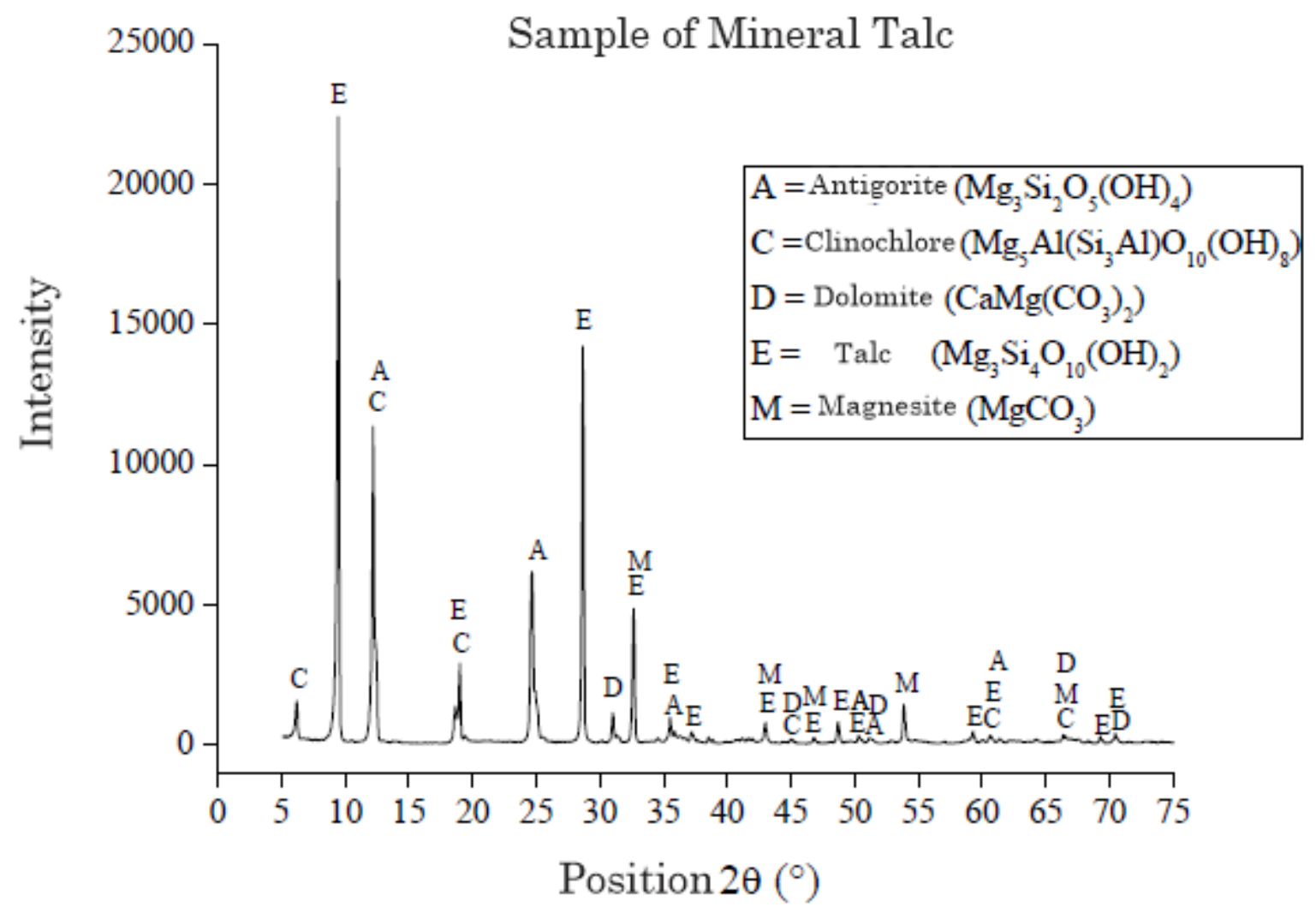

Figure 5: X - Ray Diffractogram of the ground talc sample.

The particle size distribution in the fraction $<37 \mu \mathrm{m}$ presented the highest value, and a maximum of approximately $10 \%$ for all other fractions (Figure $6(\mathrm{a})$ ). The contents of $\mathrm{Fe}, \mathrm{Ca}, \mathrm{Mg}$ and $\mathrm{Al}$, as a function of the granulometric bands, presented different behaviors and are shown in Figure 6 (b). The Fe content ( $50 \mathrm{mg} / \mathrm{g}$ ) is nearly evenly distributed in all particle size fractions. The maximum content of $\mathrm{Ca}(\sim 50 \mathrm{mg} / \mathrm{g})$ was observed in the fraction of $74 \mu \mathrm{m}$ and of $\mathrm{Al}$ in the finer fraction $(<37 \mu \mathrm{m})$. However, the $\mathrm{Mg}$ presented higher content in the fractions $<44 \mu \mathrm{m}$ and in the fractions $>74 \mu \mathrm{m}$, whereas the brightness presented similar behavior for all fractions with values greater than $50 \%$, except for the fraction retaining $37 \mu \mathrm{m}$ (Figure 6 (c)). 

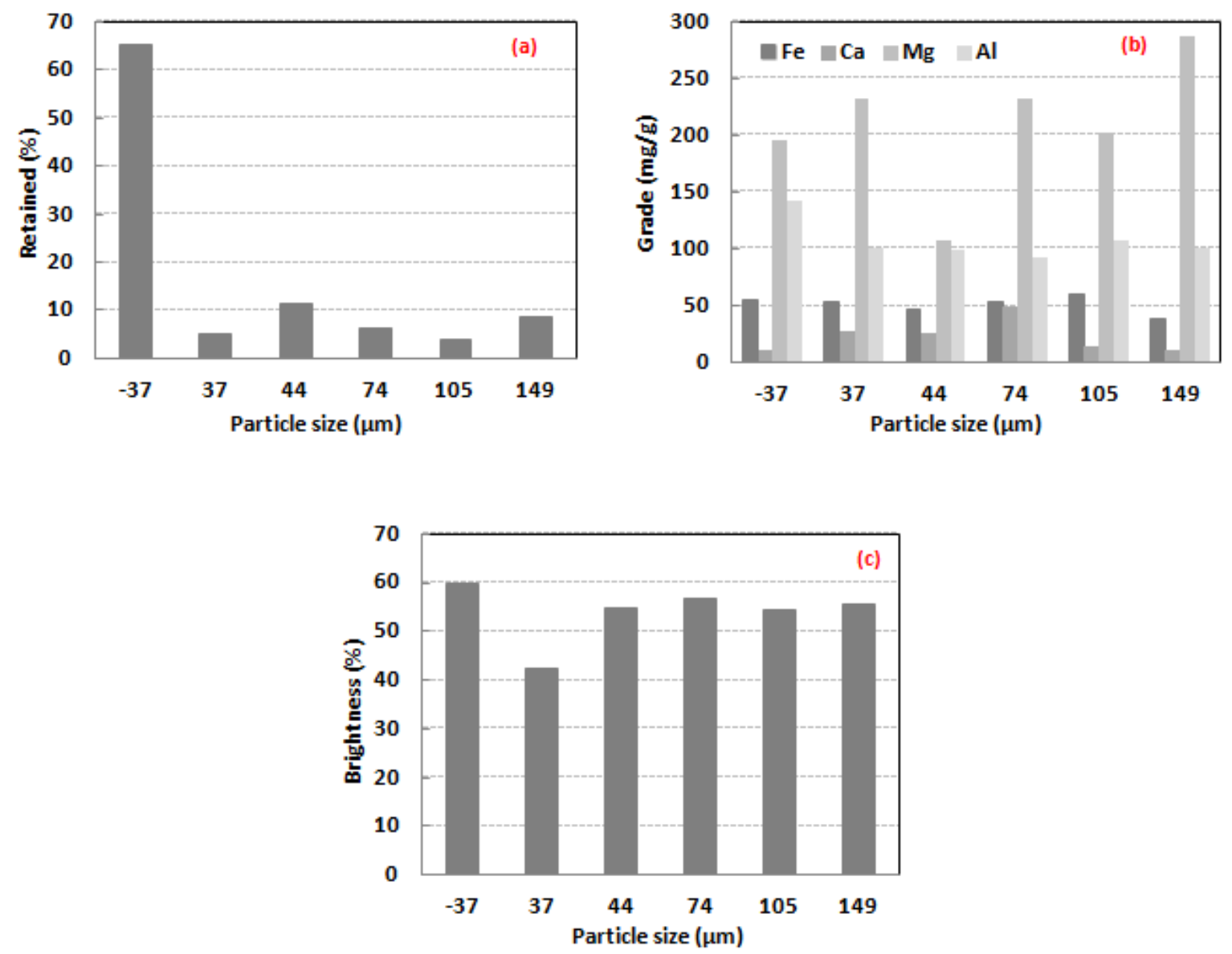

Figure 6: (a) Granulometric distribution of the ground talc sample, (b) grades and (c) brightness of each product retained.

\subsection{Magnetic separation study}

Considering the overall mass recovery, in which the losses of the granulometric cut and magnetic separation steps were evaluated, the results obtained for the cut samples (85\% and $86 \%$ ) were lower than those obtained for the samples without cutting (91\% and $94 \%$ ). The largest overall mass recovery was obtained after magnetic separation, without cutting, of the same sample (Table 4). The magnetic separation process resulted in an increase in brightness of about $5.7 \%$ in the uncut sample when subjected to a $4050 \mathrm{G}$ field and after separation the final brightness analysis showed very close results ( $64 \%)$.

Table 4: Magnetic separation test result.

\begin{tabular}{c|c|c|c|c|c}
\multirow{2}{*}{ Feed } & $\begin{array}{c}\text { Current (A) - } \\
\text { Magnetic field (G) }\end{array}$ & $\begin{array}{c}\text { Mass } \\
\text { Recovery (\%) }\end{array}$ & Global Recovery (\%) & \multicolumn{2}{|c}{ Brightness (\%) } \\
\cline { 5 - 6 } & $1,4-3050$ & 94 & 85 & 61 & 64 \\
\hline \hline Cut (100 \#) & $2,0-4050$ & 94 & 86 & 61 & 63 \\
\hline Cut (100 \#) & $1,4-3050$ & 94 & 94 & 59 & 64 \\
\hline No cut & $2,0-4050$ & 91 & 91 & 59 & 65
\end{tabular}




\subsection{Leaching study}

Figure 7 (a) shows the mass recovery of the products from the leaching tests at $\sim 22{ }^{\circ} \mathrm{C}$ (room temperature) and at $\sim 80 \pm 5{ }^{\circ} \mathrm{C}$. When performing the studies at $80 \pm 5{ }^{\circ} \mathrm{C}$, the recovery decreased by approximately $10 \%$ for the time interval between 10 and 60 min, stabilizing after 30 min. However, at room temperature this difference was only approximately $2 \%$, being practically constant over time, and showing that the use of temperature increases leaching kinetics. However, the difference in brightness between the products of the different temperatures was about $4 \%$ (Figure 7 (b)). The maximum brightness (72\%) was obtained after the leaching test using the magnetic separation sample with 100 \# cut, which also presented the largest increase (10 \%) in relation to the initial brightness (Table 5 ) and the lowest overall mass recovery.

Table 5: Summary of the acid leaching in different samples (tests).

\begin{tabular}{c|c|c|c|c}
\multirow{2}{*}{ Feed } & Mass Recovery (\%) & Global Recovery (\%) & \multicolumn{2}{|c}{ Brightness (\%) } \\
\cline { 3 - 5 } & & & Start & End \\
\hline \hline Ore & 69 & 69 & 59 & 65 \\
\hline$-100 \#$ & 68 & 62 & 61 & 65 \\
\hline Magnetic separation product (-100 \#) & 69 & 59 & 63 & 72
\end{tabular}
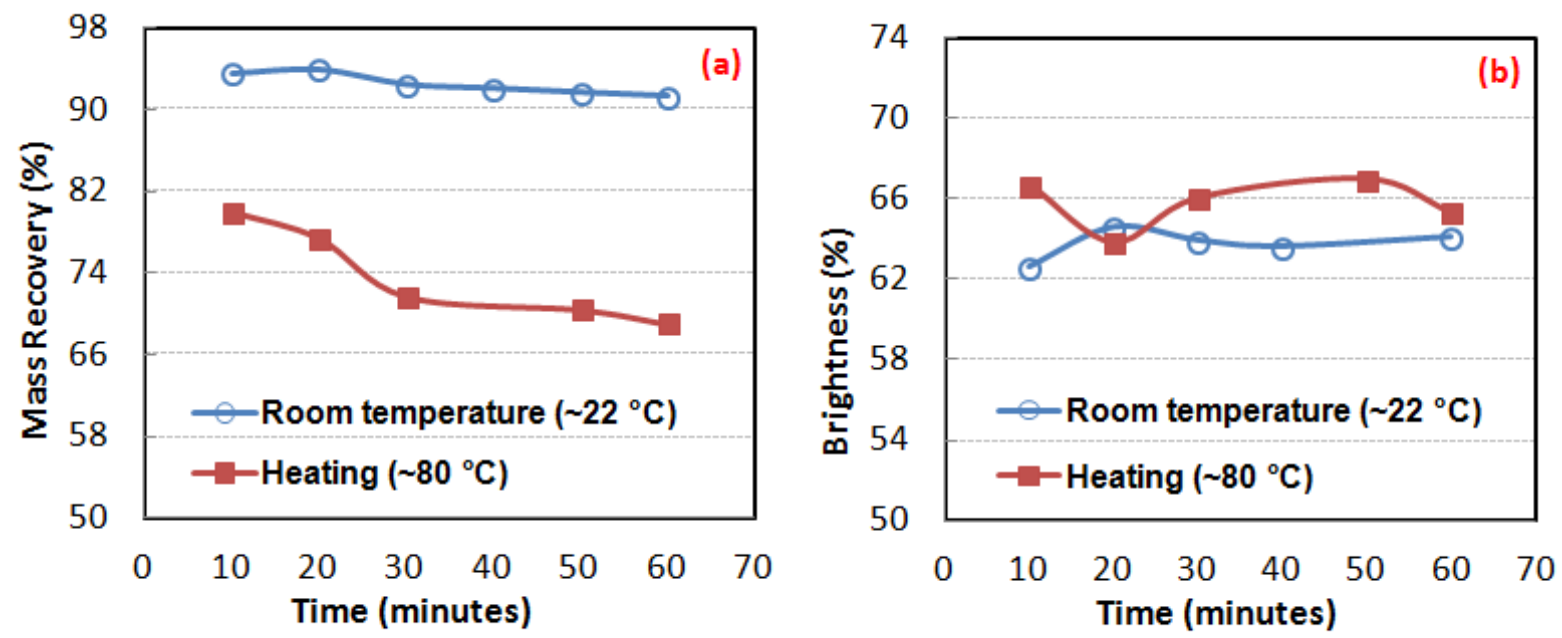

Figure 7: (a) Mass Recovery and (b) brightness of the leaching products in the ground talc sample.

\section{CONCLUSIONS}

A fine talc material ( $65 \%$ ) was obtained below $37 \mu \mathrm{m}$ after crushing and milling the sample. This granulometry must be adequate to market requirements. The distributions of $\mathrm{Fe}, \mathrm{Ca}$, $\mathrm{Mg}$ and $\mathrm{Al}$ contents of the analyzed elements presented different behaviors. The relative density of talc ore is characteristic of a silicate ore. However, the brightness showed a similarity between the values obtained for the talc ore sample, which meets the load requirements of the paper industry, although it has a high content of very reactive elements ( $\mathrm{Fe}, \mathrm{Ca}$ and $\mathrm{Mg}$ ). Also, according to the data obtained by grain size, the cut of the material retained in 100 \# did not influence the 
final brightness of the feed. As for the mineralogical characterization, it was possible to identify the 5 main phases present in the talc ore (antigorite, clinochlor, magnesite, dolomite and talc), including ore and gangue minerals.

In all magnetic separation tests, a final brightness of the non-magnetic product of approximately $64 \%$ was attained. This product could be applied in the paper industry pending a further examination of its constituent components.

The leaching studies, which involved heating, resulted in the greatest decrease of the mass recovery, which stabilized after 30 min of testing. When raising the temperature, a greater speed in the reaction of leaching was obtained, reducing the contact time between the ore and the leaching agent. These factors should be considered for future design of the leaching equipment and the need to apply heating in an industrial plant.

The best result of the study was obtained using the sample with a granulometric cut of 100 \# that was submitted to the magnetic separation $(4050 \mathrm{G})$ and later leached at $80{ }^{\circ} \mathrm{C}$ during the time of $60 \mathrm{~min}$. For this test, a maximum brightness of $72 \%$ was obtained, with an increase of $10 \%$ over the initial brightness. This product could be applied, for example, to the paint, insecticide, textile and paper industry, requiring complementary characterization to fit each specification. The costs of implementation, operation and maintenance of the application of temperature to the process should be considered. Finally, future flotation studies are suggested to verify the applicability of the process.

\section{REFERENCES}

ARIOLI, E. E., ANDRIOTTI, J. L. Silva. (2016). Representatividade da amostragem na prospecção geoquímica - CPRM. Recovered in: <http://rigeo.cprm.gov.br/xmlui/handle/doc/487>. Acess: 20/06/2016.

BITENCOURT, M. F. (1983). Geologia, petrologia e estrutura dos metamorfitos da região de Caçapava do Sul, RS. Dissertação de Mestrado. Curso de Pós-Graduação em Geociências, UFRGS. pp. 161.

CAMARA, A. L. (2003). Uso de talco nacional como aditivo adsorvente de piches e materiais pegajosos no processo de fabricação do papel. Dissertação de Mestrado. Curso de PósGraduação em Engenharia Metalúrgica e de Minas, UFMG. pp. 48-51.

CAMPOS, L. E. G. (2001). Balanço Mineral Brasileiro. Departamento Nacional de Produção Mineral - DNPM. pp.10.

FABRIS, I. L. (2006). Processamento químico do minério Talco-Silicato de Magnésio visando redução dos compostos de ferro. Dissertação de Mestrado. Programa de Pós-Graduação em Engenharia Química da Universidade Federal de Santa Catarina, UFSC. pp. 35-38; 58-85.

FONTES, A. V. (2013). Caracterização tecnológica de minério de ferro especularítico. Trabalho de conclusão do curso de Geologia. UFRJ. pp. 7-43. 
FUNDAÇÃO CRISTIANO OTTONI. (2016). Apostila do curso de Beneficiamento de Minério. Recovered in: <http://sistemas.eel.usp.br/docentes/arquivos/1922320/LOM3071/P1.6. CaracterizacaodeMinerios.pdf>. Acess: 17/06/2016.

GÓES, M. A. C de., LUZ, A. B da., POSSA, M. V. (2004). Amostragem. Tratamento de Minérios. CENTRO DE TECNOLOGIA MINERAL (CETEM). (4). pp. 44.

GONÇALVES, Í. G. (2009). Determinação da concentração de contaminantes no caolim através da teoria de Kubelka - Munk. Dissertação de Mestrado. Curso de Pós-Graduação em Engenharia de Minas, UFRGS. pp. 5.

GOÑI, J.C., GOSO, H., ISSLER, R. S. (1962). Estratigrafia e Geologia Econômica do Pré-Cambriano e Eopaleozóico Uruguaio e Sul-Riograndense. Universidade Federal do Rio Grande do Sul. (3).

HALDAR, S. K. (2012). Sampling Methods. Mineral Exploration - Principles and Applications. (7). pp. 128-129.

HECK, N. C. (2016). Notas de Aula. UFRGS - Universidade Federal do Rio Grande do Sul. Recovered in: < http://www.ct.ufrgs.br/ntcm/graduacao/ENG06631/Lixiviacao.pdf>. Acess: 18/06/2016.

KAHN, H., SANT'AGOSTINO, L.M., TASSINARI, M.M.M.L., ULSEN, C., BRAZ, A.B. (2010). Apatite from alkaline complexes-behavior in mineral processing and characterization techiniques. Beneficiation of Phosphates - Technology Advance and Adoption. 6, pp.60.

LUZ, A.B., SAMPAIO, J.A., ALMEIDA, S.L.M. (2004). Tratamento de Minérios. CETEM.4, pp. 858.

LOPES, C.G. (2012). Proveniência das rochas metassedimentares detríticas do complexo Passo Feio - Terreno São Gabriel, Caçapava do Sul - RS. Trabalho de conclusão do curso de Geologia. UFRGS. pp. 22.

MACHADO, F. B. (2016). UNESP - Universidade Estadual Paulista. Recovered in: <http://www.rc.unesp.br/museudpm/banco/silicatos/filossilicatos/talco.html>. Acess: $17 / 07 / 2016$.

MONTE, M.B.L., TRIGUEIRO, F.E., PAIVA, P.R.P. (2003). Técnicas e alternativas para a modificação do caulim. Rochas e Minerais Industriais. pp. 32.

NEUMANN, R., SCHENEIDER, C. L., NETO, A. A. (2004). Caracterização Tecnológica de Minérios. CENTRO DE TECNOLOGIA MINERAL (CETEM). (4). pp.55.

NEUMANN, R., SCHENEIDER, C. L., NETO, A. A. (2010). Caracterização Tecnológica de Minérios CENTRO DE TECNOLOGIA MINERAL (CETEM). (5). pp.85-87.

DEPARTAMENTO NACIONAL DE PRODUÇÃO MINERAL. (2010). Anuário Mineral Brasileiro. 35, pp.798. 
PONTES, I. F., ALMEIDA, S.L.M. (2005). Talco. Rochas \& Minerais Industriais - Usos e especificações. CETEM, pp. 607-628.

RIBEIRO, M., BOCCHI, P.R., FIGUEIREDO FILHO, P.M., TESSARI, R.I. (1966). Geologia da Quadrícula de Caçapava do Sul. 127, pp.232.

RIBEIRO, M. (1970). Geologia da folha de Bom Jardim: Rio Grande do Sul- Brasil. In: Boletim: Divisão de Geologia e Mineralogia. 247, pp.1-142.

RODRIGUES, M.L.M., LIMA, R.M.F. (2011). Purificação de resíduos de oficina de artesanato em pedra-sabão por flotação e alvejamento químico. REM: Revista Escola de Minas, 64 (3), pp.353357.

SAMPAIO, J. A., SILVA, F. A. N. G da. (2007). Determinação das densidades de sólidos e de polpa. Tratamento de minérios - Práticas Laboratoriais. CENTRO DE TECNOLOGIA MINERAL (CETEM). pp.40-45.

SILVA, A. C. (2012). Universidade Federal de Goiás (UFG). Concentração física de minerais. Recovered in: <https://cetm_engminas.catalao.ufg.br/up/596/o/cfm_05.pdf>. Acess: 20/06/2016.

SILVA, R. F. (2009). Operações Unitárias I. Recovered in: <http://www.ebah.com.br/content/ABAAAAtPkAD/flotacao-pdf>. Acess: 20/06/2016.

UFRGS - Universidade Federal do Rio Grande do Sul. (1998). Projeto Caçapava do Sul: Mapeamento Geológico 1:25.000.

WALKER, T. R. (1967). Formation of red beds in modern and ancient deserts. Geological Society of America Bulletin. 78, pp. 353-368.

WINGE, M. (2016). CPRM - Companhia de Pesquisa de Recursos Minerais. Recovered in: <http://sigep.cprm.gov.br/glossario/verbete/anfibolito.htm>. Acess: 15/07/2016. 